\title{
Pengembangan Rules-Driven Workflow Management System (RDWfMS) dengan Menggunakan Teknik Data Mining untuk Sistem Informasi Research Center
}

\author{
Shaufiah \\ \# School of Computing, Telkom University \\ Jl. Telekomunikasi No. 1, Ters. Buah Batu, Bandung Indonesia \\ shaufiah@telkomuniversity.ac.id
}

\begin{abstract}
Seiring dengan ketatnya persaingan bisnis dan teknologi saat ini membuat organisasi harus mampu beradaptasi sesuai dengan tuntutan perkembangan yang ada. Tuntutan perkembangan tersebut dapat menyebabkan perubahan proses bisnis dan yang selanjutnya bisa mempengaruhi sistem informasi yang sudah dimiliki oleh organisasi. Perubahan yang mungkin terjadi ini tentunya bukanlah hal yang mudah dan memerlukan waktu dan biaya yang tidak sedikit. Oleh karenanya, dalam pengembangan sistem informasi diperlukan desain yang tepat agar mudah untuk menghadapi perubahan proses bisnis, sehingga biaya pengembangan dan pemeliharaan sistem informasi dapat ditekan. Lebih lanjut, kebutuhan organisasi saat ini juga bertambah dengan adanya kebutuhan infomasi dan knowledge dari pelaksanaan bisnis dan organisasi. Salah satu pendekatan yang memungkinkan sistem informasi untuk dapat beradaptasi dengan mudah terhadap perubahan proses bisnis adalah dengan mendesain dan mengimplementasikannya berbasiskan workflow, sedangkan untuk mendapatkan informasi dan knowledge adalah dengan memanfaatkan teknik data mining dalam implementasinya. Oleh sebab itu maka penelitian ini mengembangkan sistem informasi dengan pendekatan hibrid yaitu kombinasi antara pengembangan berbasis proses workflow dan berdasarkan data yaitu teknik data mining, dengan studi kasus organisasi research center. Sistem informasi ini dinamakan dengan SIMPLER yang dibangun dengan mengadopsi penerapan rules-driven workflow yang dikombinasikan dengan teknik data mining untuk pengolahan informasi dan knowledge. Pengujian SIMPLER dilakukan dengan mengukur kemampuan SIMPLER terhadap karakteristik sebuah workflow management system dan mengukur kualitas aplikasi berdasarkan kepuasan dan persepsi end user dengan menggunakan metode WebQual. Berdasarkan hasil pengujian menunjukkan bahwa SIMPLER telah mampu memenuhi kebutuhan untuk pelaksanaan proses bisnis research center XYZ, mampu beradaptasi jika terjadi perubahan proses bisnis tanpa dilakukannya perubahan pada kode program dan mendapatkan kepuasan end user sebesar $81.81 \%$ dan akurasi sistem sebesar $85 \%$.
\end{abstract}

Kata kunci: sistem informasi, workflow, rules-driven workflow, data mining 


\begin{abstract}
Abstrak
The tight competition of business and technology today makes the organisation must be able to adapt to changes. The changes could affect not only business process model of the organisation but also their information system, which lead to high cost and time-consuming. Therefore, the design and implementation of an information system should handle with care. Furthermore, the organisation also needs to process data into information and knowledge to support their business. Hence, this research is developed to undertake those problems by developing the information system using hybrid approach of the workflow system and data mining technique with research centre organisation as a case study. The system named as SIMPLER which applying rules-driven workflow and data mining to process data into information and knowledge from research data. SIMPLER tested by measuring its ability as a workflow management system as well as measuring the quality based on end-user satisfaction and perception by using WebQual. Based on the test results indicate that the SIMPLER been able to satisfy the need for business process execution XYZ research centre, able to adapt to changes without reconstructing the source code and gained end users satisfaction of $81.81 \%$ and $85 \%$ of accuracy.
\end{abstract}

Keyword: information system, workflow, rules-driven workflow, data mining

\title{
I. PENDAHULUAN
}

$\mathrm{S}$

istem informasi di era informasi saat in merupakan salah satu ujung tombak dalam pelaksanaan proses bisnis sebuah organisasi. Banyak peran dari sistem informasi yang dapat membantu organisasi dan tentu saja banyak faktor yang menentukan kemampuan sistem informasi tersebut. Faktor-faktor tersebut diantaranya kesesuaian sistem informasi dengan kebutuhan bisnis, kehandalan dari sisi performansi dan juga yang paling penting adalah bagaimana sistem informasi dapat bersifat adaptif terhadap perubahan organisasi. Tercapainya faktor-faktor tersebut dapat diupayakan sejak dimulainya siklus manajemen proyek perangkat lunak mulai dari studi kelayakan, sampai diimplementasikannya projek. Tentu saja hal tersebut harus memperhatikan karakteristik kebutuhan bisnis dari organisasi masing-masing.

Research center merupakan organisasi yang cukup unik dan memerlukan dukungan sistem informasi yang dapat mendukung performansinya mulai dari tahapan inisiasi penelitian sampai dengan publikasi atau rilis produk penelitian. Seiring dengan mulai bergesernya kebutuhan organisasi dari hanya sekedar business process wokflow centric menjadi lebih kaya dengan data centric maka sistem informasi untuk research center ini dapat dikembangkan dengan pendekatan hibrid baik process maupun data centric.

Process centric yang dapat digunakan adalah dengan rules-driven workflow sedangkan data centric dapat memanfaatkan teknik data mining untuk mendapatkan informasi dan knowledge misalnya mengenai researcher yang cocok untuk sebuah penelitian dan topik-topik penelitian yang dapat dikembangkan lebih lanjut lagi, serta mendapatkan pola-pola tersembunyi yang menarik untuk dijadikan sebagai pendukung pengambilan keputusan oleh pihak manajemen.

Oleh karenanya penelitian ini mengimplementasikan sebuah sistem informasi manajemen penelitian yang mampu bersifat fleksibel terhadap perubahan aliran kerja atau proses bisnis dan dapat menghasilkan informasi yang dapat digunakan untuk pendukung pengambilan keputusan dengan memanfaatkkan kombinasi teknik dan metode yang sudah dikenal sebelumnya seperti rules driven workflow 


\section{STUDI LITERATUR}

\section{A. Workflow Management System (WfMS).}

Workflow adalah otomatisasi proses bisnis, baik itu secara keseluruhan maupun sebagian saja saat dokumen, informasi atau tugas diteruskan dari satu partisipan ke partisipan lainnya untuk dilakukan aksi sesuai dengan prosedur yang berlaku (Workflow handbook 1997, 1997). Partisipan disebut juga sebagai aktor atau resources yang dapat berupa mesin maupun manusia. Penelitian terkait dengan workflow telah banyak dilakukan dengan berbagai motivasi diantaranya adalah mampu meningkatkan profit yang secara khusus diteliti pada (Gruber \& Huemer, 2009) dan disebutkan pada (Caverlee et al., 2007) bahwa workflow dapat membantu transformasi perusahaan menuju arah lebih baik karena dengan workflow dimungkinkan untuk meningkatkan proses kontrol dan fleksibilitas serta memperbaiki jalannya proses bisnis. Jadi workflow dapat berfungsi untuk mengatur aliran kerja sesuai dengan standar atau aturan-aturan alur kerja yang ada pada organisasi.

Dalam pembangunan sistem informasi workflow tidak dimasukkan ke dalam source code sistem informasi tersebut, dan dikelola secara terpisah untuk memudahkan pemeliharaan dan antisipasi terhadap perubahan yang mungkin terjadi. Pengembangan dan pengimplementasian workflow memerlukan tools yang lazim disebut sebagai Workflow Management System (WfMS). Saat ini WfMS dapat dibedakan menjadi dua kelompok besar yaitu yang berorientasi pada proses, dan yang kedua kelompok yang berorientasi pada data. Contoh sistem workflow bisnis yang berorientasi pada proses adalah Business Process Management (BPM) dan yang berorientasi pada data seperti sistem InforSense(Calvo). Gambaran mengenai dua kelompok ini dapat dilihat pada gambar 2 .

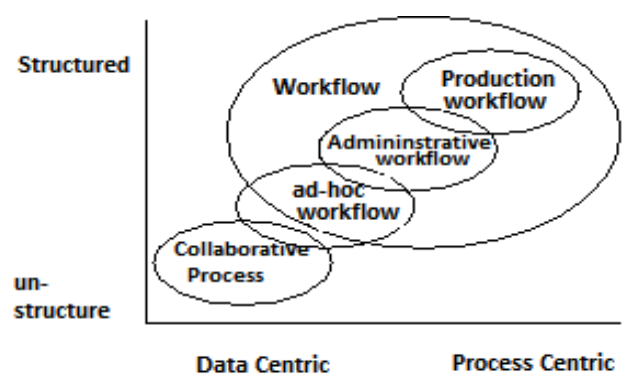

Gambar 1. Klasifikasi WfMS (Calvo)

Sebuah sistem workflow dapat dikatakan sebagai WfMS jika memiliki fungsi yang diantaranya adalah: pembuatan atau pemodelan workflow, kemampuan mengkoordinasikan dan pengaturan saat running workflow sampai dengan administrasi dan monitoring proses workflow (status workflow) (Hollingsworth \& Hampshire, 1995).

Penelitian mengenai WfMS ini telah banyak dikembangkan dalam berbagai bidang misalnya untuk perpustakaan (Places, Fariña, Luaces, Pedreira, \& Seco, 2014), web service (Fernandez, Tedeschi, \& Priol, 2016), teknologi cloud (Marozzo, Talia, \& Trunfio, 2016), bioinformatika (Mariette et al., 2016), sains (Deelman et al., 2015) dan lain sebagainya. 


\section{B. Rules-Driven Workflow}

Rules-Driven Workflow adalah workflow yang pelaksanaan aktifitasnya dikendalikan oleh rule atau sejumlah rule yang disebut juga dengan Ruleset(Wilis, 2005). Merupakan pengembangan workflow untuk aplikasi window yang dapat dijalankan pada WfMS produk Microsoft yaitu Window Workflow Foundation.

Komponen dalam Rules-Driven Workflow ini adalah rule dan policy. Rule merupakan aturan yang digunakan untuk mengendalikan sebuah workflow. Rule ditentukan berdasarkan analisis fungsi dan alur kerja pada proses bisnis. Rule ini akan disimpan dan didefinisikan dalam bentuk " if $<$ condition $>$ then $<$ action $>$ else <action>". Kumpulan rule akan menjadi Ruleset pada saat pemodelan workflow. Policy adalah kebijakan yang berasal dari tepat satu ruleset. Policy diterapkan pada workflow untuk mengatur jalannya workflow. Policy bersifat atomic jadi jika kondisi yang ada hanya mampu memenuhi sebagian saja dari rule yang ada, maka workflow dapat berada pada kondisi halt (belum selesai)(Wilis, 2005).

Motivasi penggunaan rules dalam workflow adalah karena pemodelan rule yang handal dan mudah diinterpretasikan dan diimplementasikan serta mudah untuk diubah. Gambar 2 menunjukkan ilustrasi bagaimana penerapan rules-driven workflow pada pengembangan aplikasi dengan menggunakan Window Workflow Foundation.

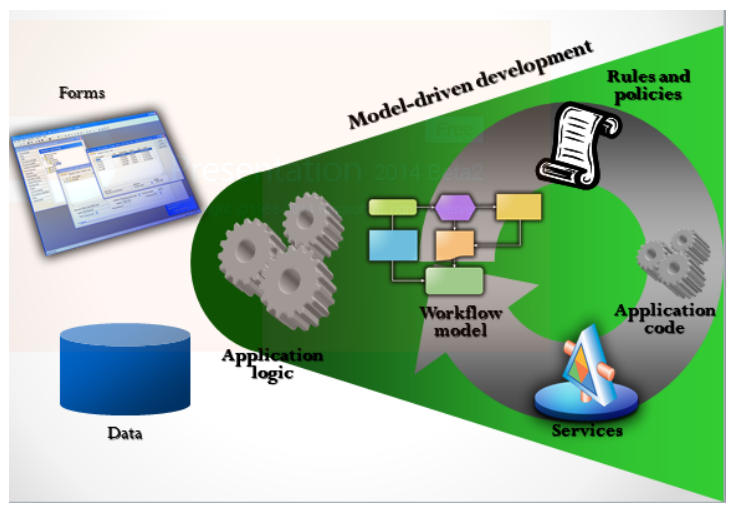

Gambar 2. Ilustrasi Penerapan Rules-Driven Workflow pada pengembangan aplikasi (Wilis, 2005)

Pada penelitian ini WfMS akan dikembangkan sendiri dengan mengadopsi konsep rules-driven workflow pada Windows Workflow Foundation.

\section{Data Mining}

Secara sederhana data mining adalah penambangan informasi atau knowledge yang baru dan sebelumnya tidak ketahui dari data yang sangat besar. Scara khusus ada yang menyatakan proses data mining dapat dilakukan baik secara semi maupun full otomatis. Data mining, sering juga disebut sebagai Knowledge Discovery in Database (KDD). KDD adalah kegiatan yang meliputi pengumpulan, pemakaian data, historis untuk menemukan keteraturan, pola atau hubungan dalam set data berukuran besar (Jiawei, Micheline, \& Jian, 2011).

Penerapan data mining dapat meliputi berbagai bidang seperti kesehatan, marketing, pendidikan dan lain sebagainya. Penerapan di berbagai bidang ini dengan memanfaatkan task yang ada contohnya klasifikasi, analisis asosiasi, clustering atau deteksi anomali. 
Analisis asosiasi adalah task dalam data mining yang bertujuan untuk mencari kesamaan pola data yang sering muncul secara bersamaan, atau menemukan korelasi diantara objek-objek pada data (Jiawei et al., 2011). Analisis asosiasi menghasilkan rule asosiasi yang dapat digambarkan melalui bentuk "IF-THEN" yang menyatakan hubungan co-occurrence dan sifatnya probabilistik. Rule asosiasi berbeda dengan aturan if-then logik pada umumnya yang menyatakan hubungan kausalitas. Pada rule asosiasi bagian "IF" disebut dengan antecedent sedangkan bagian "THEN" disebut dengan consequent, di mana rule asosiasi merupakan kombinasi objek (itemsets) yang setiap itemnya berbeda.

Contoh rule asosiasi yang didapatkan pada proses analisis data adalah "IF Pendidikan $=$ S3 THEN penelitian=3". Artinya bahwa dari data yang ada ditemukan pola bahwa objek dengan Pendidikan = S3 memiliki penelitian sebanyak tiga buah sehingga rule asosiasi ini dapat dimanfaatkan untuk menganalisis pola data yang menarik untuk diketahui.

Untuk mengukur kualitas atau seberapa penting tidaknya suatu aturan asosiatif dapat diketahui dengan dua parameter : Support dan Confidence.

a. Support: rasio antara jumlah transaksi yang memuat antecedent dan consequent terhadap jumlah transaksi.

b. Confidence: Rasio antara jumlah transaksi yang memuat antecedent dan consequent terhadap jumlah transaksi yang meliputi semua item dalam antecedent

Untuk mendapatkan rule asosiasi dapat digunakan algoritma asosiasi data mining dan beberapa algoritma diantaranya algoritma apriori dan varian pengembangannya, FP-Growth dan pengembangannya seperti algoritma CT-Pro dan lain sebagainya. Pada penelitian ini analisis asosiasi dilakukan dengan menggunakan algoritma apriori, karena apriori merupakan algoritma asosiasi yang telah terbukti banyak digunakan, mudah, sederhana dan memiliki performansi yang baik dalam berbagai implementasi. Implementasi algortima apriori pada penelitian ini memanfaatkan tools data mining yang sudah ada yaitu WEKA (Mark et al., 2009).

\section{E. Klasifikasi dan Nä̈ve Bayes Classfier}

Klasifikasi adalah proses pencarian sekumpulan model atau fungsi yang menggambarkan dan membedakan kelas data dengan tujuan agar model tersebut dapat digunakan untuk memprediksi kelas dari suatu obyek yang belum diketahui kelasnya (Mark et al., 2009). Terdapat dua proses utama pada klasifikasi yaitu pembangunan klasifikasi dan penggunaan model tersebut. Model klasifikasi dapat disajikan dalam berbagai macam model klasifikasi seperti Naïve Bayes, decision trees, Bayesian classification, k-nearestneighbourhood classifier, neural network dan lain sebagainya. Pada penelitian ini digunakan Naïve Bayes karena classifier ini sederhana untuk diimplementasikan namun terbukti cukup baik dalam melakukan proses klasifikasi.

Naïve Bayes merupakan salah satu metode machine learning yang menggunakan perhitungan probabilitas yang dikemukakan oleh Thomas Bayes, yaitu menghitung nilai probabilitas kategori dan semua data yang ada. Perhitungan probabilitas tersebut menggunakan persamaan (Jiawei et al., 2011):

$$
p\left(k_{x}\right)=\frac{f_{j}\left(k_{x}\right)}{|j|}
$$

dengan:

$p\left(k_{x}\right)=$ probabilitas kelas $k_{x}$ dalam data training

$f_{j}\left(k_{x}\right)=$ jumlah nilai atribut dengan kategori $k_{x}$

$|j|=$ jumlah nilai atribut dalam data 
Pada penelitian ini Naïve Bayes Classifiier dihasilkan dengan menggunakan tools WEKA(Mark et al., 2009).

\section{F. Pengukuran Kepuasan Website}

Pengembangan aplikasi website tentunya harus dievaluasi agar mendapatkan hasil yang sesuai dengan harapan, khususnya saat ini di mana end user menjadi sasaran utamanya. Pengukuran kepuasan website sendiri banyak digunakan dengan berbagai pendekatan misalnya. Adapun untuk tingkat penerimaan workflow sistem dapat juga dievaluasi dengan pendekatan misalnya UTAUT yang dilakukan (Mosweu, Bwalya, \& Mutshewa, 2016), namun pada penelitian ini tingkat penerimaan user terhadap sistem workflow akan dievaluasi dengan menggunakan webQual. WebQual merupakan teknik pengukuran kualitas website berdasarkan persepsi end user berdasarkan tiga area yaitu, (1) kualitas informasi, (2) interaksi dan kualitas layanan, (3) usability dari human computer interaction, serta dan kepuasan secara menyeluruh (overall impression) (Barnes \& Vidgen, 2000).

Persepsi end user yang dimaksud pada WebQual dibedakan menjadi persepsi mutu layanan yang dirasakan secara aktual dengan tingkat harapan yang ideal. Untuk mendapatkan data persepsi tersebut diperlukan pengumpulan data dengan metode survei. Selanjutnya hasil survei harus diolah dan diuji dari sisi validitas dan realibilitas. Dalam penelitian ini, butir pertanyaan pada survei akan menggunakan skala likert yang dengan lima tingkatan yang terdiri dari sangat tidak puas (1), tidak puas (2), biasa (3), puas (4), sangat puas (5).

\section{METODE PENELITIAN}

Penelitian ini termasuk dalam jenis action research, yaitu penelitian yang berupaya melakukan penyelesaian masalah melalui proses reflektif untuk meningkatkan strategi, praktek dan pengetahuan dalam lingkup tertentu (Riel., 2010-2017). Adapun langkah-langkahnya adalah studi literatur, analisis kebutuhan desain dan implementasi, evaluasi dan pelaporan akhir yang digambarkan pada pada gambar 3 .

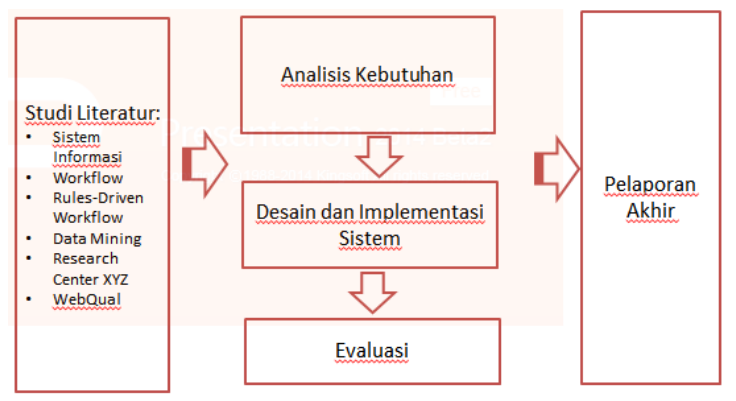

Gambar 3. Metodologi Penelitian

\section{A. Studi literatur}

Merupakan tahapan untuk mengkaji literatur yang relevan dengan penelitian ini seperti mengenai: sistem informasi, workflow, data mining dan WebQual yang didapatkan dari berbagai sumber buku cetak, paper, jurnal, dokumen internal organisasi dan referensi yang berasal dari internet dan telah dipaparkan pada bagian II jurnal ini.

\section{B. Analisis Kebutuhan}

Merupakan tahapan untuk mengumpulkan dan mengkonfirmasikan kebutuhan sistem informasi yang dibangun sesuai dengan hasil studi literatur dan wawancara dengan stakeholder terkait. Adapun proses bisnis Research Center XYZ yang telah dikumpulkan adalah sebagai berikut: 
Research Center XYZ merupakan sebuah divisi yang bertanggung jawab terhadap riset baik yang bersifat basic science maupun riset untuk pengembangan layanan serta produk teknologi. Riset yang dilaksanakan pada Research Center XYZ dapat dibedakan menjadi 2 yaitu:

- Riset yang merupakan usulan dari researcher

- Riset yang merupakan ketetapan sesuai roadmap riset organanisasi dan kebutuhan bisnis yang ada.

Adapun sumber pendanaan riset ini berasal baik dari internal organisasi maupun dari pihak eksternal. Sedangkan jangka waktu riset sendiri baik untuk riset yang berasal dari usulan researcher maupun yang merupakan ketetapan organisasi dapat berlangsung tahun tunggal maupun multi tahun.

Tak dapat dipungkiri sistem informasi tentunya sangat diperlukan dalam rangka pengelolaan, monitoring dan analisis untuk pengukuran dan peningkatan performansi riset yang ada. Selain itu sistem informasi dibutukan sebagai sarana komunikasi antara researcher, project manager, pemangku dana dan stakeholder lainnya.

Kepentingan pihak manager misalnya agar manager dapat memonitor sejauh mana progress projek/riset yang dikerjakan. Dan khusus untuk riset yang bersifat strategis sesuai ketetapan organisasi membutuhkan sistem informasi untuk memilih researcher yang memiliki kompetensi yang tepat dan cocok untuk mengerjakan sebuah projek riset. Permasalahan yang terkadang muncul adalah pemilihan researcher yang tidak sesuai dengan projek riset yang ada, sehingga mengakibatkan riset tersebut berjalan tidak seperti yang diharapkan. .

Kebutuhan lain yang diperlukan untuk ada dalam sistem informasi adalah fasilitas untuk melihat tingkat partisipasi dan keterlibatan seorang researcher dalam rangka penilaian kinerja. Selain itu juga perlu adanya penjadwalan riset dan jadwal project researcher sehingga pemangku kepentingan (manager dan lainnya yang terkait) dapat memonitor jadwal harian dan jadwal project researcher. Pemetaan user dan kebutuhannya terhadap sistem dapat dipetakan ke dalam pengguna seperti pada tabel 1 berikut ini.

Tabel 1 Daftar Pengguna SIMPLER

\begin{tabular}{|l|l|l|l|}
\hline Kategori & Tugas & $\begin{array}{l}\text { Hak Akses ke } \\
\text { aplikasi }\end{array}$ & Kemampuan yang harus dimiliki \\
\hline Direktur & $\begin{array}{l}\text { Manage data } \\
\text { View activity } \\
\text { Execute activity }\end{array}$ & User Direktur & $\begin{array}{l}\text { Dapat menggunakan komputer beserta web } \\
\text { browsernya }\end{array}$ \\
\hline Manager & $\begin{array}{l}\text { Manage data } \\
\text { View activity } \\
\text { Execute activity }\end{array}$ & $\begin{array}{l}\text { User Manager } \\
\text { Dapat menggunakan komputer beserta web } \\
\text { browsernya }\end{array}$ \\
\hline IT Staff & $\begin{array}{l}\text { Manage data } \\
\text { Execute activity }\end{array}$ & $\begin{array}{l}\text { User } \\
\text { Researcher }\end{array}$ & $\begin{array}{l}\text { Dapat menggunakan komputer dan web } \\
\text { browsernya }\end{array}$ \\
\hline RWDS SIMPLER & Inferensia Workflow & $\begin{array}{l}\text { Aplikasi } \\
\text { Eksternal }\end{array}$ & $\begin{array}{l}\text { Memahami database dan jaringan yang } \\
\text { digunakan }\end{array}$ \\
\hline
\end{tabular}


Adapun detil dari fungsionalitas yang sesuai dengan kebutuhan proses bisnis Research Center XYZ yang harus dipenuhi oleh SIMPLER adalah sebagai berikut:

1. Registrasi di dalam SIMPLER

2. LogIn dan Logout

3. Create, Update, Read, Delete project research yang sedang dikerjakan

4. Create, Update, Read, Delete semua researcher (termasuk CV, sertifikasi, dan track record researcher).

5. Create, Update, Read, Delete jadwal project research

6. Create, Update, Read, Delete job research

7. Create, Update, Read, Delete jadwal job research harian

8. Create, Update, Read, Delete progress

9. Create, Update, Read, Delete wbs project research

10. Analisis penentuan researcher

11. Report project research

12. Report performansi researcher

13. Monitoring dan Search project researcher tertentu

14. Monitoring dan Search job researcher tertentu

15. Monitoring dan Search project research semua researcher

16. Monitoring dan Search project researcher tertentu

17. Monitoring dan Search profil researcher tertentu

\section{Desain dan implementasi sistem}

Tahpan ini merupakan fase memodelkan dan merancang sistem informasi yang dibangun berdasarkan tahapan analisis kebutuhan yang sudah didapatkan sebelumnya. Hasil desain digambarkan melalui diagram use case, diagram aktivitas dan diagram deployment untuk selanjutnya diimplementasikan, Sistem Informasi yang dikembangkan ini dinamakan dengan SIMPLER dengan yang terdiri dari dua bagian: rule driven-workflow system development dan yang kedua end user interface application. Adapun dokumen yang harus dicreate oleh SIMPER adalah research proposal, reporting document (progress and final report), researcher performance report.

Sesuai dengan gambar 4 WfMS yang dikembangkan pada penelitian ini adalah Rules-driven workflow yang mengadopsi rules-driven workflow pada Windows Workflow Foundation. Terdiri dari beberapa use case yaitu:

1. Manage workflow yang akan bertanggung jawab untuk pembentukan model workflow yang akan digunakan pada organisasi

2. Manage Activity yang bertanggung jawab mendefinisikan aktivitas-aktivitas yang ada pada proses bisnis. Activity yang didefinisikan ini akan berperan pada pengeksekusian data pada end user interface application SIMPLER

3. Manage Transition bertanggungjawab terhadap hubungan antar aktivitas dan merupakan dasar dari sebuah workflow.

4. Manage Rule and Policy yang bertanggung jawab untuk pendefinisian rule dan policy yang digunakan sebagai acuan pelaksanaan proses bisnis. Termasuk di dalamnya rule yang didapatkan dari proses data mining terhadap data di research center XYZ.

5. Monitoring yang bertanggungjawab untuk memonitor keseluruhan proses yang ada. 

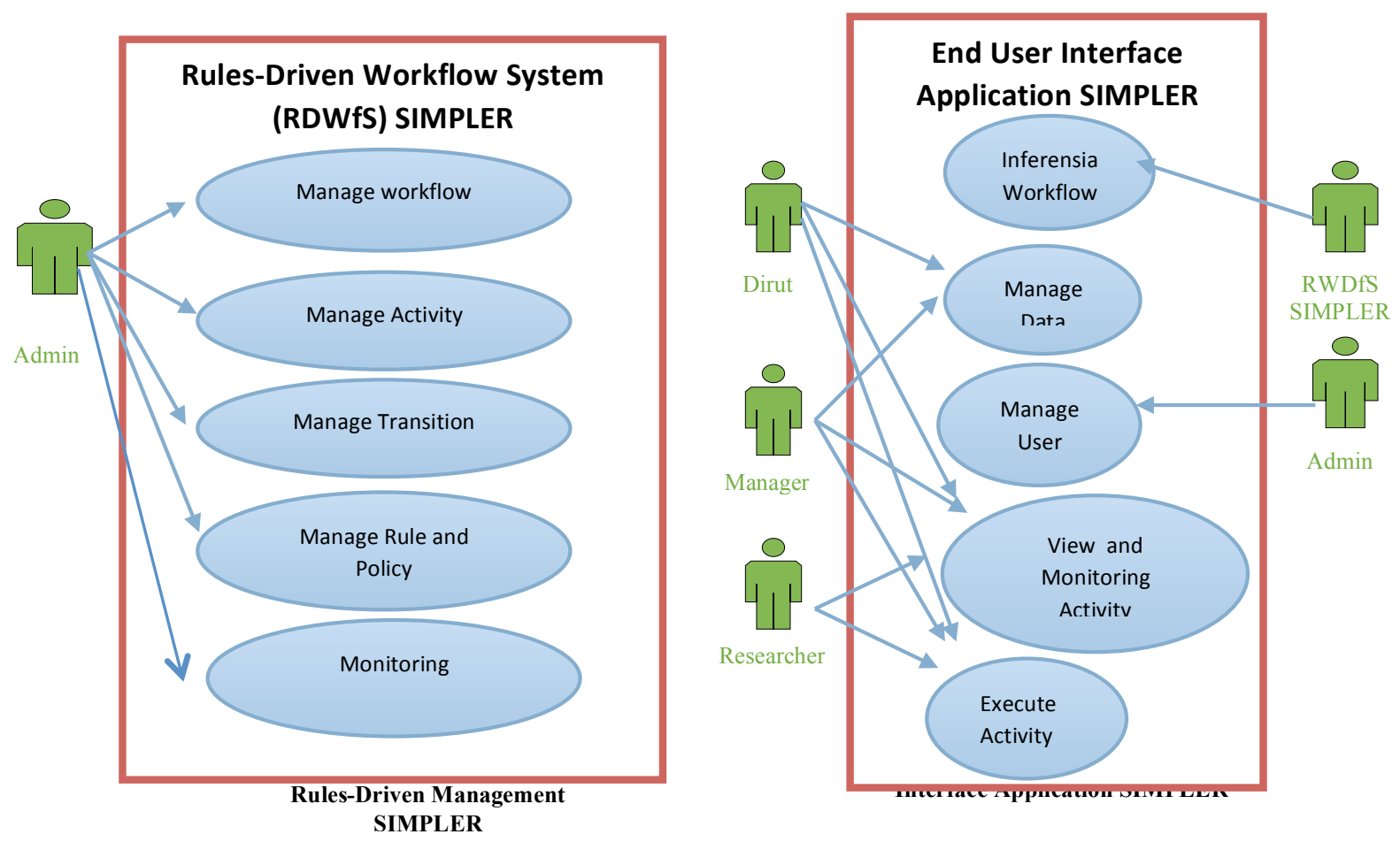

Sesuai dengan gambar 5 end user interface application SIMPLER terdiri dari use case:

1. Inferensia workflow yang akan bertanggung jawab untuk pengaturan workflow

2. Manage data yang bertanggung jawab untuk mengelola data yang diperlukan pada sistem SIMPLER.

3. Manage user bertanggungjawab terhadap pengelolaan user dan otoritasnya pada SIMPLER.

4. View and Monitoring activity yang bertanggung jawab untuk melihat dan memonitor aktivitas workflow.

5. Execute activity yang bertanggungjawab untuk mengekseskusi aktivitas pada workflow.

Desain data mining untuk fungsionalitas analisis penentuan researcher dilakukan terpisah dan hasil akhir berupa model saja yang disimpan pada SIMPLER untuk diimplementasikan. Desain data mining untuk penentuan researcher disajikan pada gambar 6, dimana terdapat beberapa proses dimulai dari:

1. Data proyek riset, data researcher dan data jadwal riset yang sebelumnya sudah mengalami proses preprocessing yaitu stopword, stemming dan tokenisasi data yang dilakukan di luar sistem akan menjadi data training untuk proses data mining

2. Learning data mining adalah proses pengaplikasian data mining yaitu asosiasi dan klasifikasi untuk data training dengan menggunakan algoritma naïve bayes dan apriori, yang akan mengeluarkan output berupa model kandidat researcher.

3. Model yang dihasilkan pada proses 2 akan dievaluasi apakah sudah memenuhi standar minimal atau belum, jika sudah maka akan dipilih untuk digunakan sebagai model researcher. Jika tidak sesuai standar minimal maka proses learning data mining akan diulang dari awal. Output model researcher ini selanjutnya akan digunakan sebagai rule researcher pada sistem workflow. 
ShaufiaH

Pengembangan Rules-Driven...

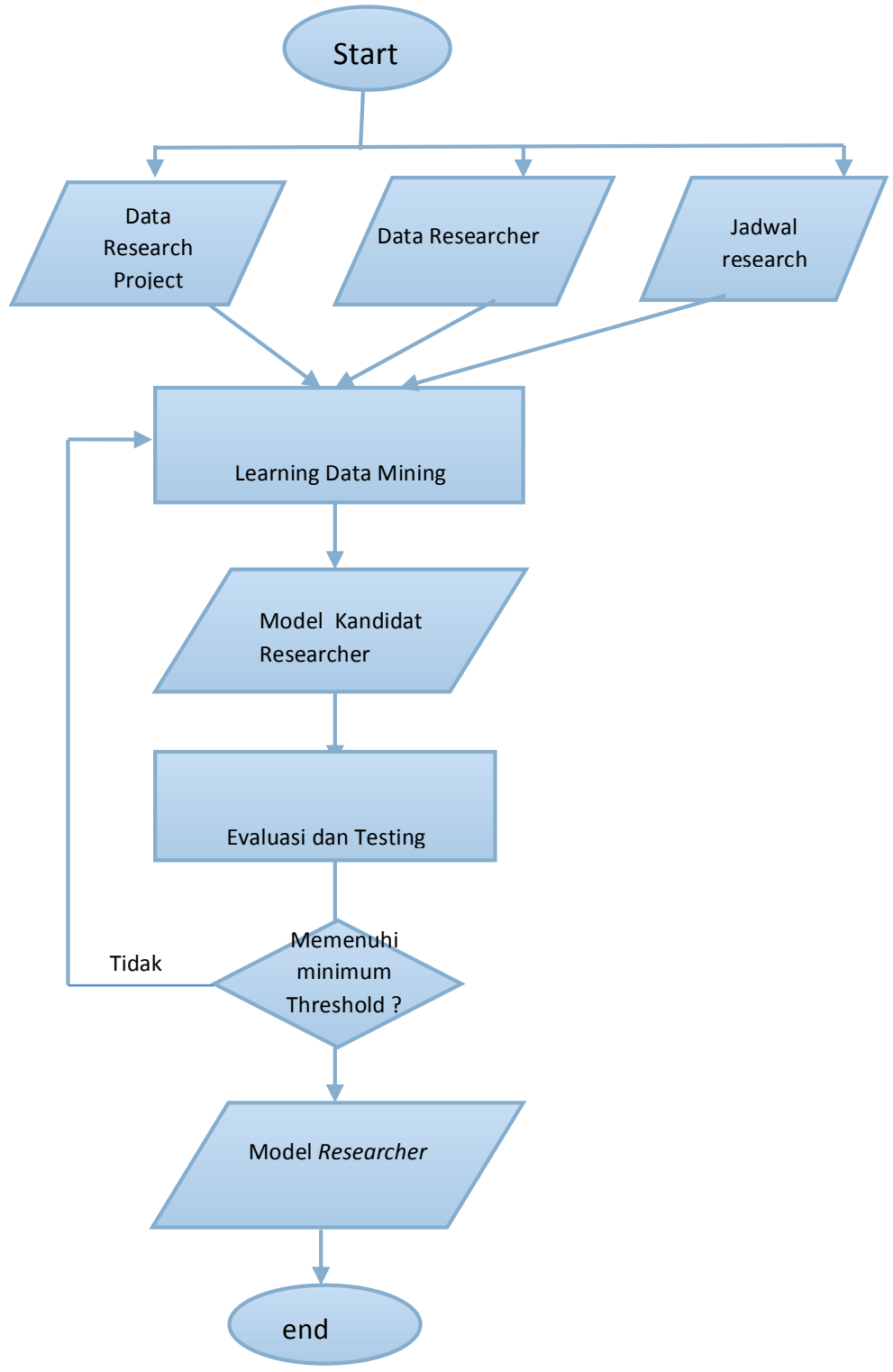

Gambar 6. Gambaran Proses Analisis Penentuan Researcher dengan teknik Data Mining

Selanjutnya, beberapa contoh desain SIMPLER berdasarkan proses bisnis dapat dilihat pada gambar 7 memperlihatkan bagaimana data calon researcher akan disimpan dan selanjutnya akan digunakan untuk tahapan analisis data. Selanjutnya, gambar 8 menunjukkan proses bisnis kelola activity project di mana usernya adalalah manager/ admin yang akan dapat melihat dan memilih menu pengelolaan project yang disediakan oleh SIMPLER sedangkan gambar 9 memperlihatkan urutan aktivitas yang melibatkan manager, researcher dan SIMPLER dalam pengelolaan acitivity researcher. Proses bisnis ini memungkinkan user manager untuk melihat, menambahkan dan mengubah data researcher pada SIMPLER. 


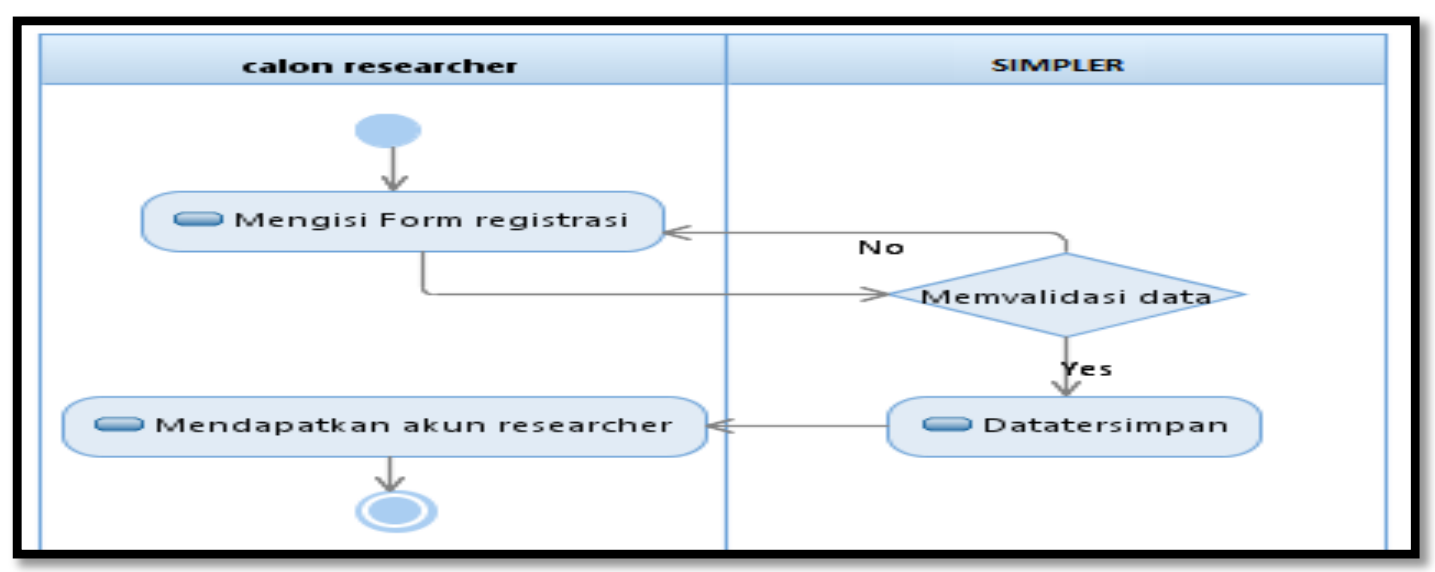

Gambar 7. Proses Bisnis Pendaftaran akun researcher pada SIMPLER

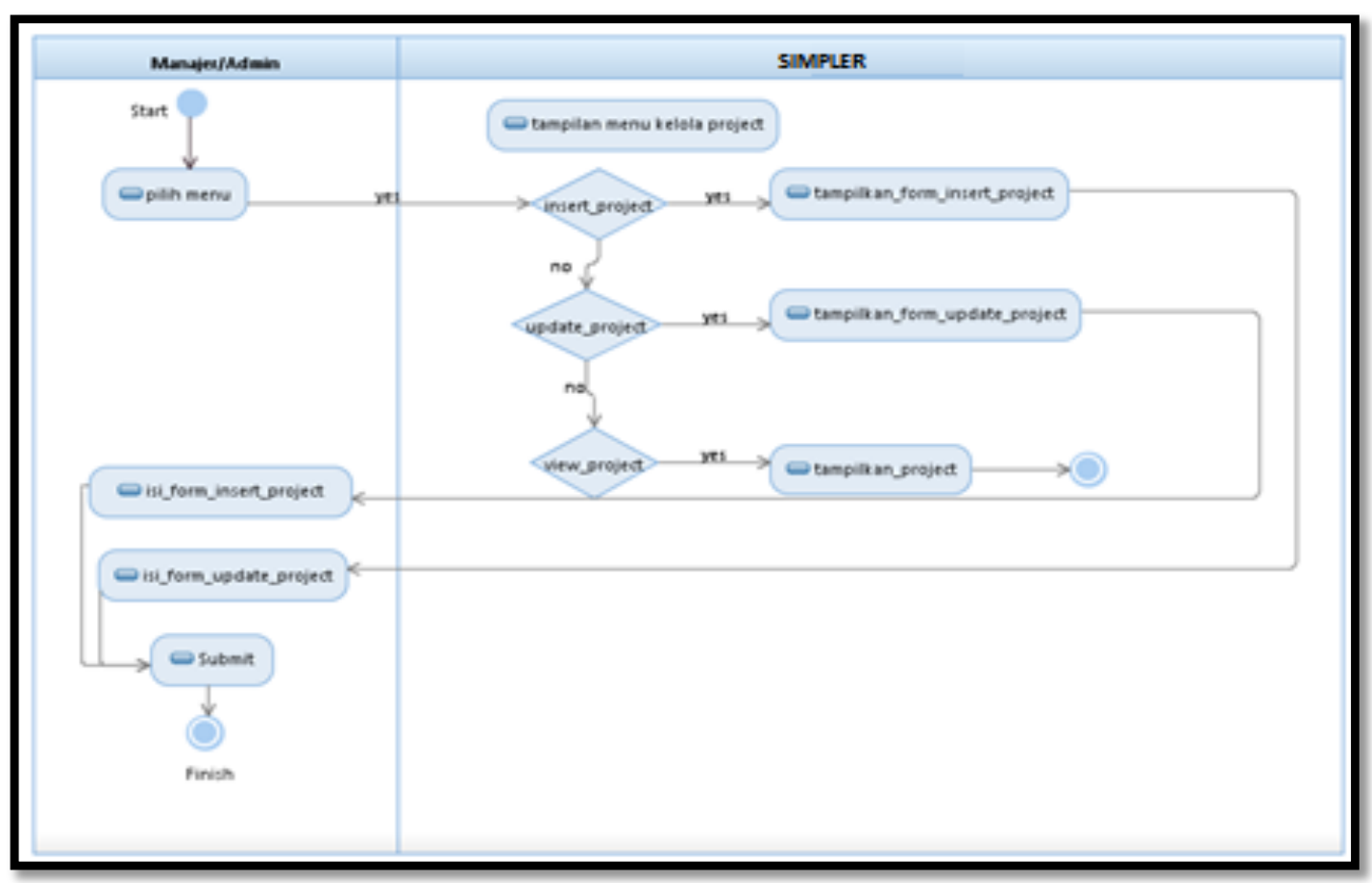

Gambar 8. Proses Bisnis Kelola Activity Project SIMPLER 


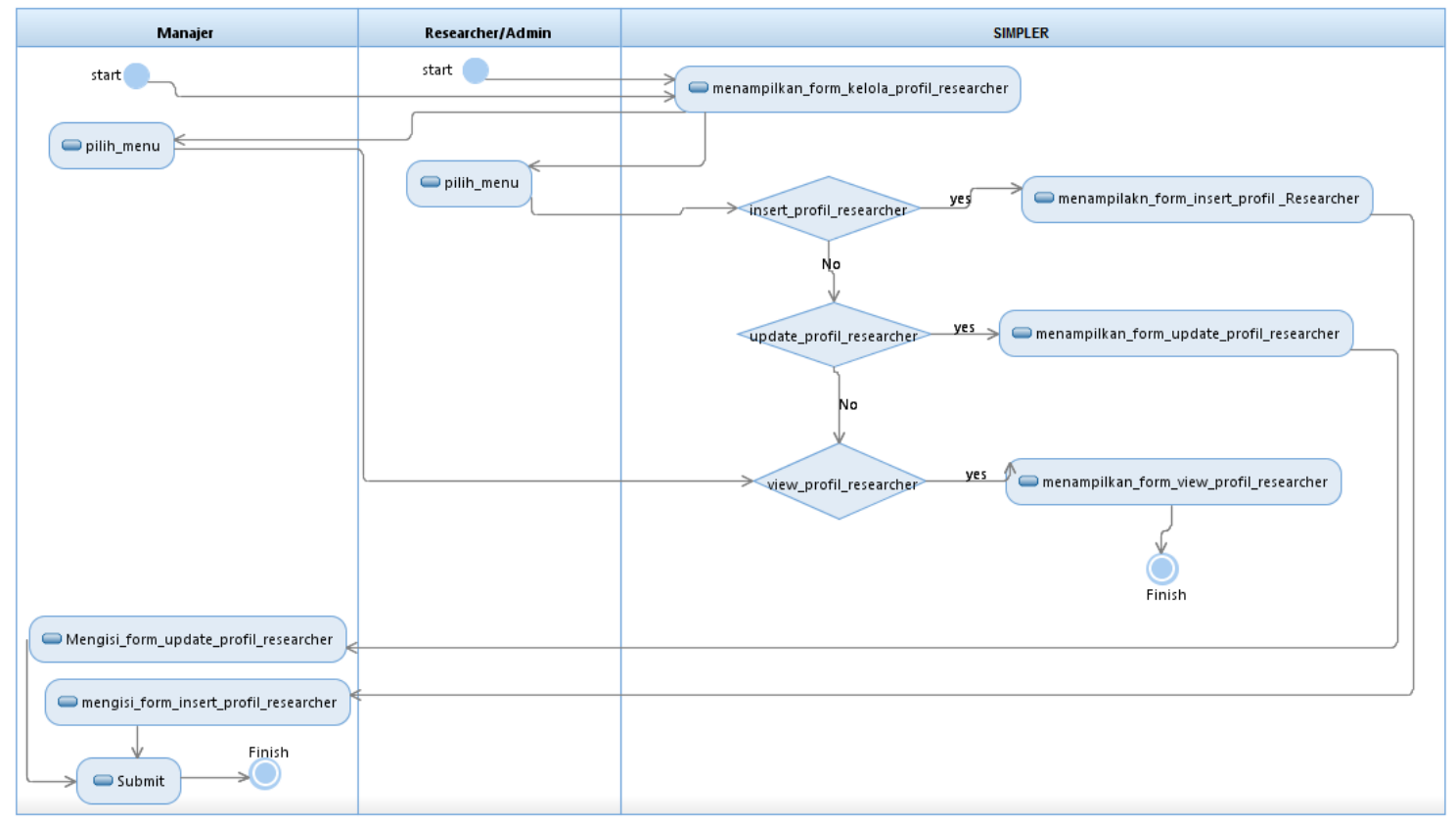

Gambar 9. Proses Bisnis Kelola Activity Researcher SIMPLER

Secara umum implementasi dari SIMPLER ini digambarkan dengan diagram deployment pada gambar 10 berikut. Dapat terlihat bahwa komponen hardware yang terlibat dalam SIMPLER ini adlah web server, database server dan application server.

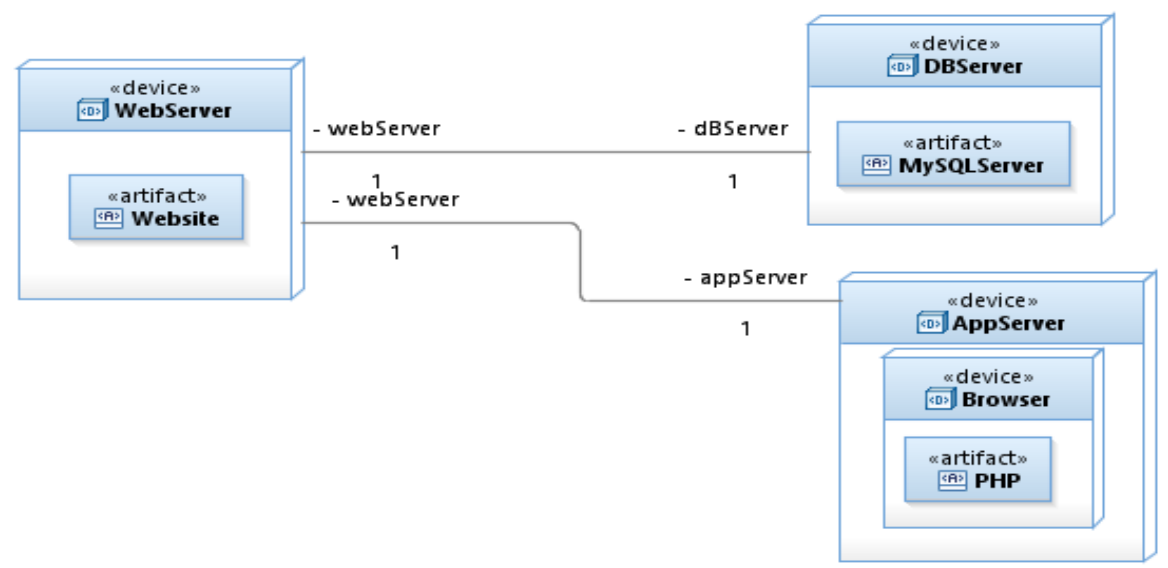

Gambar 10. Deployment Diagram SIMPLER

\section{Evaluasi dan Analisis}

Pada tahapan ini dilakukan pengujian dan analisis terhadap SIMPLER. Pengujian SIMPLER dilakukan untuk mengetahui apakah SIMPLER sudah memenuhi syarat sebagai WfMS seperti yang sudah dijelaskan 
pada sub bab 2 bagian A ditambah dengan pengujian untuk mengukur kepuasan SIMPLER sebagai produk sistem informasi. Adapun tahapan dan tujuan pengujian SIMPLER, yaitu:

1. Pengujian untuk menjamin kualitas dan kelengkapan fungsionalitas Rules-Driven Wokflow (RDWfS) SIMPLER yang terdiri dari:

a. Pengujian kemampuan memodelkan workflow

b. Pengujian kemampuan untuk mengkoordinasikan dan mengatur saat workflow dieksekusi

c. Pengujian penanganan exception

d. Pengujian adaptasi terhadap perubahan alur proses.

2. Pengujian kesesuaian fungsionalitas dan aktivitas pada workflow dengan kebutuhan proses bisnis yang ada

3. Pengujian kepuasan dan persepsi end user terhadap SIMPLER. Dalam penelitian ini digunakan metode WebQual. Kuesioner disampaikan kepada responden yaitu end user SIMPLER pada Research Center XYZ sejumlah 5 orang yang dan pengujian penggunaan SIMPLER secara langsung.

\section{HASIL DAN PEMBAHASAN}

Berdasarkan penelitian yang dilakukan, maka didapatkan hasil sebuah wfms SIMPLER yang mengadopsi rules driven workflow yang dikombinasikan dengan teknik data mining yaitu asosiasi dan klasifikasi untuk sebuah research center XYZ. Berdasarkan skenario 1 yang sudah dipaparkan sebelumnya, SIMPLER diuji dengan beberapa tahapan, dan hasilnya adalah sebagai berikut:

\section{A. Evaluasi dan Analisis Rules-Driven Workflow (RDWfS) SIMPLER}

Pengujian kemampuan RDWfS SIMPLER dilakukan dengan mengimplementasikan alur kerja proyek riset di Research Center XYZ ke dalam RDWfS SIMPLER. Yang dianalisis adalah hasil aktivitas dan transisi dengan rincian pada tabel 2. Hasil pengujian kemampuan untuk mengeksekusi alur kerja sesuai dengan aktivitas workflow yang telah didefinisikan sebelumnya dan kemampuan menangani eksepsi ditunjukkan pada tabel 3, dan hasil pengujian beradaptasi terhadap perubahan proses bisnis pada tabel 4 .

Tabel 2 Hasil Pengujian kemampuan RDWfS SIMPLER memodelkan wokflow

\begin{tabular}{|c|l|c|c|}
\hline \multirow{2}{*}{ No } & \multicolumn{1}{|c|}{ Alur Kerja } & \multicolumn{1}{c|}{ Hasil } \\
Eksekusi & Status \\
Pemodelan & Acitivity \\
\hline 1 & $\begin{array}{l}\text { Inisiasi Proyek riset lalu penentuan } \\
\text { personel researcher sampai dengan } \\
\text { terbitnya proposal riset }\end{array}$ & Berhasil & $\begin{array}{c}\text { Sesuai } \\
\text { dengan } \\
\text { urutan yang } \\
\text { diharapkan }\end{array}$ \\
\hline 2 & $\begin{array}{l}\text { Monitoring dan Evaluasi proyek riset } \\
\text { sampai dengan terbitnya dokumen laporan } \\
\text { riset dan dokumen performansi riset dan } \\
\text { researchernya }\end{array}$ & Berhasil & $\begin{array}{c}\text { Sesuai } \\
\text { dengan } \\
\text { urutan yang } \\
\text { diharapkan }\end{array}$ \\
\hline
\end{tabular}




\begin{tabular}{|c|c|c|c|}
\hline No & Alur Kerja & $\begin{array}{c}\text { Hasil } \\
\text { Eksekusi } \\
\text { Pemodelan }\end{array}$ & $\begin{array}{c}\text { Status } \\
\text { Acitivity }\end{array}$ \\
\hline 3 & Edit dan Koreksi terhadap proyek riset & Berhasil & $\begin{array}{c}\text { Sesuai } \\
\text { dengan } \\
\text { urutan yang } \\
\text { diharapkan }\end{array}$ \\
\hline
\end{tabular}

Berdasarkan hasil pada tabel 2 terlihat bahwa RDWfS SIMPLER berhasil memodelkan workflow sesuai dengan urutan yang diharapkan dari 3 skenario yang diujikan yaitu inisiasi proyek riset sampai rilis, monitoring dan evaluasi royek riset dan juga edit dan koreksi terhadap proyek riset. Hal ini menunjukkan RDWfS SIMPLER telah memenuhi kriteria pertama sebuah sistem workflow.

Tabel 3 Hasil Pengujian kemampuan RDWfS SIMPLER Menangani Exception

\begin{tabular}{|l|l|c|}
\hline No & \multicolumn{1}{|c|}{ Skenario Alur Kerja } & $\begin{array}{c}\text { Hasil Eksekusi } \\
\text { dan Recovery }\end{array}$ \\
\hline 1 & $\begin{array}{l}\text { Proses Inisiasi Proyek riset lalu penentuan personel } \\
\text { researcher terhenti di tengah jalan sebelum proses } \\
\text { akhir terbitnya proposal riset selesai dijalankan }\end{array}$ & Berhasil \\
\hline 2 & $\begin{array}{l}\text { Monitoring dan Evaluasi proyek riset terhenti di tengah } \\
\text { jalan sebelum proses akhir sampai dengan terbitnya } \\
\text { dokumen laporan riset dan dokumen performansi riset } \\
\text { dan researchernya sebelum proses selesai dijalankan }\end{array}$ & Berhasil \\
\hline 3 & $\begin{array}{l}\text { Edit dan Koreksi terhadap proyek riset terhenti di } \\
\text { tengah jalan sebelum proses selesai dijalankan }\end{array}$ & Berhasil \\
\hline
\end{tabular}

Berdasarkan hasil pada tabel 3 terlihat bahwa RDWfS SIMPLER mampu menangai exception berdasarkan tiga skenario, di mana masing-masing skenario mengindikasikan proses atau aktivatas berhenti di tengah jalan. Hasilnya didapatkan bahwa RDWfS SIMPLER mampu mengidentifkasi eksekusi yang terhenti di tengah jalan tersebut dan berhasil untuk melakukan recovery sesuai dengan dengan urutan yang diharapkan. Hal ini menunjukkan RDWfS SIMPLER telah memenuhi kriteria kedua dari sebuah sistem workflow.

Tabel 4 Hasil Pengujian kemampuan Adaptasi RDWfS SIMPLER Terhadap Perubahan Alur Kerja

\begin{tabular}{|l|l|c|c|}
\hline No & Skenario Awal Alur Kerja & $\begin{array}{c}\text { Skenario Perubahan } \\
\text { Alur Kerja }\end{array}$ & Hasil \\
& & & Eksekusi \\
\hline \multirow{4}{*}{1} & Aktivitas 1--> Aktivitas 2--> & Aktivitas 1--> Aktivitas 2- & \\
& Aktivitas 3--> Aktivitas 4 --> & $->$ Aktivitas 3--> Aktivitas \\
& Aktivitas 5 --> Aktivitas 6--> & 4 --> Aktivitas 5 --> \\
& Aktivitas 7 & Bktivitas 6--> Aktivitas 7 & \\
\hline
\end{tabular}




\begin{tabular}{|c|c|c|c|}
\hline No & Skenario Awal Alur Kerja & $\begin{array}{c}\text { Skenario Perubahan } \\
\text { Alur Kerja }\end{array}$ & $\begin{array}{c}\text { Hasil } \\
\text { Eksekusi }\end{array}$ \\
\hline 2 & $\begin{array}{ll}\text { Aktivitas } 1--> & \text { Aktivitas 2--> } \\
\text { Aktivitas } 7-->\text { Aktivitas } 6 \text {--> } \\
\text { Aktivitas } 4-->\text { Aktivitas } 3--> \\
\text { Aktivitas } 5\end{array}$ & $\begin{array}{c}\text { Aktivitas 1--> Aktivitas 2- } \\
->\text { Aktivitas 3--> Aktivitas } \\
4 \text {--> Aktivitas } 5 \text {--> } \\
\text { Aktivitas 6--> Aktivitas } 7\end{array}$ & Berhasil \\
\hline 3 & $\begin{array}{l}\text { Aktivitas 8--> Aktivitas 9--> } \\
\text { Aktivitas 10--> Aktivitas } 11 \text {-- } \\
>\text { Aktivitas } 12-->\text { Aktivitas 13- } \\
->\text { Aktivitas 14--> Aktivitas 15 }\end{array}$ & $\begin{array}{c}\text { Aktivitas 8--> Aktivitas 9- } \\
->\text { Aktivitas 13--> } \\
\text { Aktivitas } 14-->\text { Aktivitas } \\
15 \text {--> Aktivitas 10--> } \\
\text { Aktivitas } 11-->\text { Aktivitas } \\
12\end{array}$ & Berhasil \\
\hline
\end{tabular}

Tabel 4 menunjukkan bahwa RDWfS SIMPLER mampu berdaptasi terhadap perubahan proses bisnis yang diwakili oleh perubahan urutan aktivitas dengan dicobakan pada tiga scenario alur kerja. Perubahan urutan aktivitas ini dapat diatur pada RDWfS SIMPLER dan hasilnya dapat berjalan dengan baik seperti pada skenario 2, awalnya aktivitas dimulai dengan urutan 1-2-7-6-4-3-5, kemudian diasumsikan ada perubahan proses bisnis yang diwakili oleh aktivitas 1-2-3-4-5-6-7, dan hasil eksekusi menunjukkan bahwa perubahan urutan aktivitas tersebut tetap dapat dijalankan tanpa melakukan perubahan pada kode program pada aplikasi SIMPLER. Hal ini menunjukkan RDWfS SIMPLER telah memenuhi kriteria ketiga dari sebuah sistem workflow.

Secara keseluruhan dari hasil pengujian berdasarkan tabel 2 sampai dengan tabel 4 menunjukkan bahwa $R D W f S$ SIMPLER dapat dikatakan sebagai sebuah WfMS karena telah memiliki kemampuan yang menjadi kriteria dasar sebuah WfMS dan dapat menangi perubahan alur kerja tanpa memerlukan pengkodean ulang pada aplikasi yang sudah ada.

B. Pengujian kesesuaian fungsionalitas dan aktivitas pada workflow dengan kebutuhan proses bisnis yang ada

Untuk mencapai kesesuaian fungsionalitas dan aktivitas pada workflow dengan kebutuhan proses bisnis yang ada, maka dapat ditampilkan dengan matrik yang memnunjukkan kebutuhan proses bisnis yang ada dengan fungsionalitas yang sudah disediakan oleh RDWfS SIMPLER seperti pada tabel 5 yang dapat disimpulkan bahwa RDWfS SIMPLER ini telah memenuhi fungsionalitas yang dibutuhkan oleh Research Center XYZ dan masih memungkinkan untuk beradaptasi terhadap perubahan proses yang terjadi pada Research Center XYZ di masa yang akan datang. 
Tabel 5 Matriks Pemetaan Kesesuaian Fungsional FRDWfS SIMPLER dengan Kebutuhan Proses Bisnis

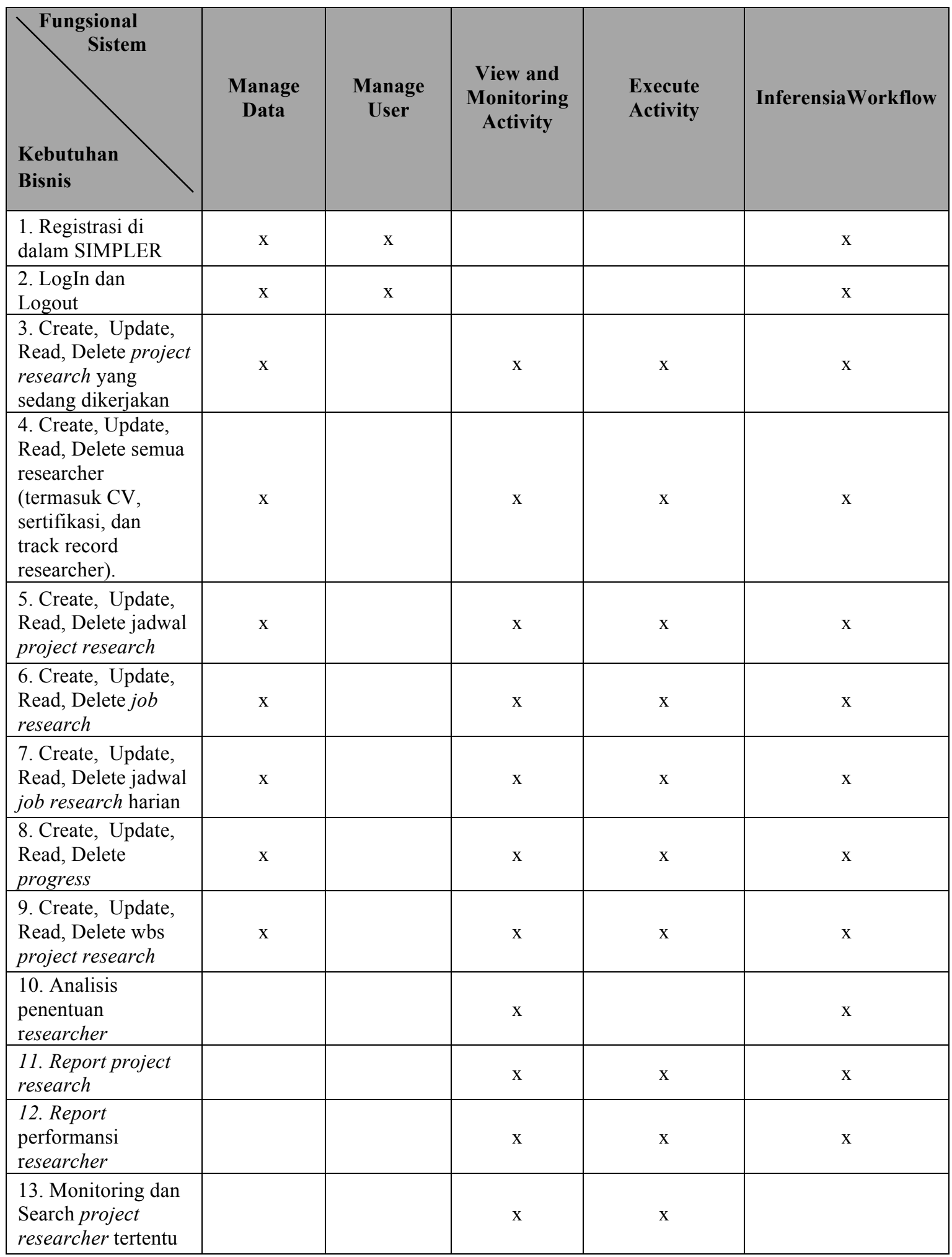




\begin{tabular}{|l|c|c|c|c|c|}
\hline \multicolumn{1}{|c|}{$\begin{array}{c}\text { Sistem } \\
\text { Kebutuhan } \\
\text { Bisnis }\end{array}$} & $\begin{array}{c}\text { Manage } \\
\text { Data }\end{array}$ & $\begin{array}{c}\text { Manage } \\
\text { User }\end{array}$ & $\begin{array}{c}\text { View and } \\
\text { Monitoring } \\
\text { Activity }\end{array}$ & $\begin{array}{c}\text { Execute } \\
\text { Activity }\end{array}$ & InferensiaWorkflow \\
\hline $\begin{array}{l}\text { 14. Monitoring dan } \\
\text { Search } \text { job } \\
\text { researcher tertentu }\end{array}$ & & $\mathrm{x}$ & $\mathrm{x}$ & $\mathrm{x}$ & \\
\hline $\begin{array}{l}\text { 15. Monitoring dan } \\
\text { Search } \text { project } \\
\text { research semua } \\
\text { researcher }\end{array}$ & & $\mathrm{x}$ & $\mathrm{x}$ & $\mathrm{x}$ & \\
\hline $\begin{array}{l}\text { 16. Monitoring dan } \\
\text { Search project } \\
\text { researcher tertentu }\end{array}$ & & & $\mathrm{x}$ & & \\
\hline $\begin{array}{l}\text { 17. Monitoring dan } \\
\text { Search profil } \\
\text { researcher tertentu }\end{array}$ & & & & & \\
\hline
\end{tabular}

C. Pengujian Modul Data Mining untuk RDWfS SIMPLER

Modul data mining yang digunakan pada RDWfS SIMPLER ini menggunkaan dua teknik yaitu analisis asosiasi dan klasifikasi yang ditanam pada use case Manage Rule and Policy. Analisis asosiasi dievaluasi dengan menggunakan parameter minimum support dan confidence, sedangkan evaluasi klasifikasi dilakukan dengan menggunakan 10 -fold cross validation untuk mendapatkan nilai akurasi.

Dari hasil pengujian minimum suppot dan minimum confidence yang terbaik untuk analisis asosiasi researcher yang tepat pada sebuah proyek di Research Center XYZ adalah minsup $=0.2$ dan minconf $=0.6$. Sedangkan akurasi klasifikasi terbaik yang didapatkan adalah sebesar $85 \%$. Hal ini menunjukkan bahwa rule yang dihasilkan oleh teknik data mining asosiasi dan klasifikasi sudah cukup baik dalam menunjang analisis data researcher pada RDWfS SIMPLER.

D. Pengujian kepuasan dan persepsi end user terhadap SIMPLER

Pengujian kepuasan dan persepsi end user terhadap SIMPLER dilakukan dengan memberikan kuesioner kepada sejumlah 5 oranng end user SIMPLER. Dari semua atribut yang diteliti, responden menyatakan penilaian puas pada keseluruhan variabel. Rincian tingkat kepuasan pada keempat dimensi yang ada ditunjukkan pada tabel 6 - tabel 9 .

Tabel 6 Tingkat Kepuasan RDWfS SIMPLER Berdasarkan Dimensi Usability

\begin{tabular}{|c|l|c|}
\hline No & \multicolumn{1}{|c|}{ Atribut Dimensi Usability } & Mean Kepuasan \\
\hline 1. & Kemudahan aplikasi untuk dipelajari & 3.75 \\
\hline 2. & Kemudahan untuk dioperasikan & 4.25 \\
\hline
\end{tabular}




\begin{tabular}{|c|l|c|}
\hline 3. & Kemudahan untuk navigasi & 4.25 \\
\hline 4. & Loading aplikasi yang cepat & 3.75 \\
\hline
\end{tabular}

Pada dimensi Information Quality, mayoritas responden menyatakan penilaian puas pada 3 variabel dan penilaian sangat puas pada 1 variabel. Hasil analisis tingkat kepuasan dapat dilihat pada tabel berikut.

Tabel 7 Tingkat Kepuasan RDWfS SIMPLER pada Dimensi Information Quality

\begin{tabular}{|c|l|c|}
\hline No & \multicolumn{1}{|c|}{ Atribut Information Quality } & $\begin{array}{c}\text { Mean } \\
\text { Kepuasan }\end{array}$ \\
\hline 1. & Menyediakan informasi yang akurat & 4.25 \\
\hline 2. & $\begin{array}{l}\text { Menyediakan informasi secara cepat } \\
\text { (realtime) }\end{array}$ & 4 \\
\hline 3. & $\begin{array}{l}\text { Menyediakan informasi yang mudah } \\
\text { dimengerti }\end{array}$ & 3,75 \\
\hline 4. & $\begin{array}{l}\text { Menyediakan informasi dengan format yang } \\
\text { tepat }\end{array}$ & 4,75 \\
\hline
\end{tabular}

Pada dimensi Interaction Quality, mayoritas responden menyatakan penilaian puas pada 2 variabel, dan penilaian cukup puas pada 1 variabel. Hasil analisis ini dapat dilihat pada tabel berikut.

Tabel 8 Tingkat Kepuasan RDWfS SIMPLER pada Dimensi Interaction Quality

\begin{tabular}{|c|l|c|}
\hline No & \multicolumn{1}{|c|}{ Atribut Interaction Quality } & Mean Kepuasan \\
\hline 1. & Merasakan kenyamanan dengan aplikasi & 4 \\
\hline 2. & Rancangan aplikasi yang menarik & 4 \\
\hline 3 & $\begin{array}{l}\text { Keinteraktifan fitur yang membantu } \\
\text { mencapai tujuan }\end{array}$ & 4.25 \\
\hline
\end{tabular}

Pada dimensi kepuasan secara keseluruhan atau overall impression, mayoritas responden menyatakan puas, dengan nilai median 4 . Hasil analisis dapat dilihat pada tabel berikut.

Tabel 9 Tingkat Kepuasan RDWfS SIMPLER pada Dimensi Overall Impression

\begin{tabular}{|c|l|c|}
\hline No & \multicolumn{1}{|c|}{ Atribut Dimensi Overall Impression } & Mean Kepuasan \\
\hline 1. & $\begin{array}{l}\text { Kepuasan secara menyeluruh terhadap } \\
\text { aplikasi }\end{array}$ & 4 \\
\hline
\end{tabular}

Jika dirata-ratakan maka kepuasan terhadap RDWfS SIMPLER adalah sebesar: 4.1 dari 5 atau sebesar $81.81 \%$. Hasil ini dapat dikatakan end user merasa puas dengan RDWfS SIMPLER.

\section{KESIMPULAN}

Kesimpulan yang diperoleh dari penelitian ini adalah sebagai berikut:

1. RDWfS SIMPLER dapat dikategorikan sebagai sebuah WfMS karena berdasarkan pengujian sudah memenuhi kriteria minimum sebuah WfMS yaitu dapat memodelkan workflow, dapat 
mengkoordinasikan dan mengatur saat workflow dieksekusi mengatur aktivitas, dan mampu menangani exception pada saat eksekusi aktivitas .

2. RDWfS SIMPLER terbukti mampu beradaptasi terhadap perubahan alur proses bisnis yang mungkin terjadi pada research center XYZ sehingga pengelolaan sistem informasi ini dapat lebih mudah untuk dilakukan karena tidak harus merubah dan mengkodekan ulang aplikasi.

3. Data Mining dapat diintegrasikan dengan rules driven workflow untuk menghasilkan rule dan knowledge yang dapat menunjang proses bisnis sebuah research center

4. End user dari RDWfS SIMPLER merasa puas dengan prosentase sebesar $81.81 \%$ dengan pengukuran berdasarkan WebQual.

5. Implementasi data mining yaitu task asosiasi untuk kasus ini optimal pada saat nilai minimum support sebesar 0.2 dan minimum confidence sebesar 0.6 dan akurasi dari klasifikasi Naïve Bayes yang dihasilkan untuk modul analisis researcher adalah sebesar $85 \%$.

\section{REFERENSI}

Barnes, S., \& Vidgen, R. (2000). WebQual: an exploration of website quality. ECIS 2000 Proceedings, 74.

Calvo, R. A. Workflow Management Systems [Powerpoint slides]. Retrieved from http://mark.aufflick.com/files/view/talks/5.1-workflows.ppt

Caverlee, J., Bae, J., Wu, Q., Liu, L., Pu, C., \& Rouse, W. B. (2007). Workflow management for enterprise transformation. Information Knowledge Systems Management, 6(1, 2), 61-80 \%@ 1389-1995.

Deelman, E., Vahi, K., Juve, G., Rynge, M., Callaghan, S., Maechling, P. J., . . Wenger, K. (2015). Pegasus, a workflow management system for science automation. Future Generation Computer Systems, 46, 17-35. doi:10.1016/j.future.2014.10.008

Fernandez, H., Tedeschi, C., \& Priol, T. (2016). A Chemistry-Inspired Workflow Management System for Decentralizing Workflow Execution. IEEE Transactions on Services Computing, 9(2), 213-226. doi:10.1109/tsc. 2013.27

Gruber, H., \& Huemer, C. (2009). Profitability Analysis of Workflow Management Systems. 233-238. doi:10.1109/cec.2009.34

Hollingsworth, D., \& Hampshire, U. K. (1995). Workflow management coalition: The workflow reference model. Document Number TC00-1003, 19.

Jiawei, H., Micheline, K., \& Jian, P. (2011). Data Mining: Concepts and Techniques: Morgan Kaufmann Publishers Inc.

Mariette, J., Escudie, F., Bardou, P., Nabihoudine, I., Noirot, C., Trotard, M. S., . . Klopp, C. (2016). Jflow: a workflow management system for web applications. Bioinformatics, 32(3), 456-458. doi:10.1093/bioinformatics/btv589

Mark, H., Eibe, F., Geoffrey, H., Bernhard, P., Peter, R., \& Ian, H. W. (2009). The WEKA data mining software: an update. SIGKDD Explor. Newsl. \%@ 1931-0145, 11(1), 10-18. doi: $10.1145 / 1656274.1656278$

Marozzo, F., Talia, D., \& Trunfio, P. (2016). A Workflow Management System for Scalable Data Mining on Clouds. IEEE Transactions on Services Computing, 1-1. doi:10.1109/tsc.2016.2589243

Mosweu, O., Bwalya, K., \& Mutshewa, A. (2016). Examining factors affecting the adoption and usage of document workflow management system (DWMS) using the UTAUT model. Records Management Journal, 26(1), 38-67. doi:10.1108/rmj-03-2015-0012

Places, Á. S., Fariña, A., Luaces, M. R., Pedreira, Ó., \& Seco, D. (2014). A workflow management system to feed digital libraries: proposal and case study. Multimedia Tools and Applications, 75(7), 3843-3877. doi:10.1007/s11042-014-2155-3

Riel., M. (2010-2017, (Last revision Jan, 2017). Understanding Action Research. (Last revision Jan, 2017). (Last revision. Retrieved from http://cadres.pepperdine.edu/ccar/define.html

Wilis, J. (2005). Developing Rules Driven Workflows in Windows Workflow Foundation [Powerpoint slides]. Retrieved from http://www.blog.blanar.net/files/COM318_Willis.ppt

.Workflow handbook 1997. (1997): John Wiley \& Sons, Inc. 
